\title{
Technological Adaptation to a Platform and Dependence: Value Co-creation through Partnerships
}

\author{
Yong Kyu Lew \\ Associate Professor of International Business \\ College of Business, Hankuk University of Foreign Studies, Seoul, Korea \\ (Corresponding author E-mail: yklew@hufs.ac.kr)
}

Junic Kim

Assistant Professor of Strategy

School of Business, Konkuk University, Seoul, Korea

\author{
Zaheer Khan \\ Professor of International Business \\ Kent Business School, University of Kent, Canterbury, UK \\ z.a.khan@kent.ac.uk
}

Acknowledgment:

This work was supported by Hankuk University of Foreign Studies Research Fund

Note: This is a pre-print post peer review accepted version, please cite:

Lew, Y.K., Kim, J., \& Khan, Z. (2019). Technological Adaptation to a Platform and Dependence: Value Co-creation through Partnerships, Asian Journal of Technology

Innovation, in press. 


\begin{abstract}
This article examines technology exchange mechanisms in technological platform partnerships between software and hardware firms. Such firms form complementary partnerships to develop innovative technological products in the mobile telephony sector. Data were collected from 110 high-tech firms which have formed technological platform partnerships, and analysed data, by using partial least squares structural equation modelling. The results show that a focal firm's technological complexity and technological adaptation to its partner's platform increase its dependence on a partner, which in turn positively affects value co-creation in such partnerships. Complementary technological collaboration through adaptation-dependence between technological partners helps resolve knowledge accessibility and technological integration for value co-creation and innovation between heterogeneous partners from different high-tech industries. This study provides a clue as to how technological partners co-create value in the high-tech industry.
\end{abstract}

Keywords: adaptation; complexity; dependence; partnership; platform; value co-creation 


\section{INTRODUCTION}

How do heterogeneous technological firms co-create value through forming partnerships? The semantics of heterogeneity indicates the uniformity in character, often assumed in the analysis on a firm and inter-firm level research. The existing literature has attempted to uncover value-creating mechanisms in partnerships between cooperating firms owning unique resources and capabilities (Ireland et al., 2002, Wang and Rajagopalan, 2015). For instance, inter-firm governance research on partnerships has focused on how to control for curbing opportunism in a partnership (Burkert et al., 2012, Yu et al., 2006, Carson et al., 2003). Value is increasingly being created through the use of multi-alliance partnerships and ecosystem of value creating firms where firms configure their novel resources in a unique fashion to create value (Adner and Kapoor, 2010, Amit and Han, 2017). It is in such context that Ireland et al. (2002, p.251) suggest, 'alliances are used to develop a collection of valuecreating resources that a firm cannot create independently'. In a similar vein, Wang and Wang and Rajagopalan (2015, p.251) indicate, 'partnering firms have the opportunity to create value by leveraging complementary assets and learning from each other while dealing with the challenges posed by conflicts, unexpected contingencies, and moral hazards'.

Research on partnership and learning argues that cooperating firms race on learning and acquisition of a partner's knowledge, thus limiting partnership longevity (Zeng and Chen, 2003, Khanna et al., 1998). Furthermore, studies on value appropriation in the technology management literature note on solutions for protecting valuable resources from partners, e.g., patent, secrecy, and monitoring (Gulati and Singh, 1998, Katila et al., 2008). These studies indicate a dilemma in a partnership how to maximize value creation while minimizing interpartners' risks and opportunism. Such studies fundamentally assume the heterogeneity that an individual firm's value creation mechanism differs from each other due to its own resources and organizational capabilities for exploiting these resources (Sydow et al., 2009, Wernerfelt, 
1984). Thus, knowledge and know-how hoarding and protection are main concerns to even collaborative partners.

In particular, with the advent of smartphones the technology exchange mechanism is becoming more rapidly in the context of the co-creation of technological partnerships in the mobile telephony industry and the ICT-based cloud platform shows various types of value chains (Basole and Karla, 2011, Kim, 2018). Today's mobile telephony is one of the fastestchanging industries in the high-tech industry, and extant studies have been working on value co-creation and partnership (see e.g., Parker et al., 2016a, Cecere et al., 2015, Parker et al., 2016b). As such, the mobile telephony industry is an ideal context to investigate platform partnerships in that small and big hardware and small platform providers cooperate each other to develop innovative technological architecture in this sector.

Recent research on knowledge and partnership provides a fresh typology of knowledgeaccessing partnership, distinguishing from knowledge-acquisition one (Grant and BadenFuller, 2004, Lew et al., 2016). Regarding the first type, acquisition of a partner's knowledge may not be a main concern but aims to access complementary knowledge/resources of a partner, thus the importance of exploration and combination of these knowledge and resources for value creation (Lavie et al., 2009). In other words, a partnership is not necessarily being a temporary vehicle to learn something from the partner as the main purpose of a certain type of partnership (e.g., knowledge-accessing) is not to broaden knowledge base through acquisition, but taking advantage of knowledge specialization of each partner (Nissen et al., 2008, Postrel, 2002, Lew et al., 2016). As such, it is vital to understand inter-firm dynamics of knowledge/resource exchange process in a platformoriented partnerships due to the embedded nature of knowledge within a given platform (Gawer and Cusumano, 2014). In this regard, there are studies on partnership adaptation (Zollo et al., 2002) and dependence (Bae and Insead, 2004). Yet, they focus on contractual 
adaptation, governance structure changes, and asymmetric power and their influences on performance consequences, theoretically drawing on transaction cost economics (Williamson, 1991) and resource-dependence theory (Pfeffer and Salancik, 1978a). Also, there is a cognate relationship management literature investigating dynamic adaption and dependence issues on a resource exchange process at a network level (Hallén et al., 1991, Mukherji and Francis, 2008, Håkansson and Snehota, 1995).

In the modern technology and digitalization eras, a technological firm's adaptive behaviors are affected by technological complexity (Hallén et al., 1991) and dominant technologies and technological platform (Gereffi et al., 2005, Meyer and Seliger, 1998, Gawer and Cusumano, 2008). Moreover, a high-tech firm's core competence becomes specialized, which hinders comprehending a partner's knowledge/resources in a partnership (Kim et al., 2016). Thus, investigating how these specialized firms collaborate with each other and co-create value will broaden our understanding on these firms' orchestrate and reconfigure their technological resources for value creation. However, these approaches have their own limitations to fully explain technological resource exchange mechanisms in partnerships between contemporary high-tech firms due to the rise of digitization since capabilities are spread across partners being part of an ecosystem (Adner and Kapoor, 2010)

Unlike the aforementioned previous partnership research on adaptation and dependence, this research takes a fresh technological approach on examining the mechanisms of how cooperative high-tech firms with their own resources from different sectors create value. To do this, it employs the concept of a platform (Gawer and Cusumano, 2014, Gawer, 2014) and links it to business -to- business relationship issues on adaptation and dependence in partnerships between the software company and the hardware company from the technological perspective. While the traditional business has a structure of linear value chain that creates value through the linear steps from manufacturers to consumers, platform 
business shows the complicated value chain, which has various streams among manufacturers, consumers and a platform provider. Thus, researchers investigated that platform model creates network effects based on various mechanisms and relationships (Parker et al., 2016b, McIntyre and Srinivasan, 2017). In this paper, a partner' platform indicates a set of promised technological protocols between partners, which glues interfirm relationship between technologically complementary partners (Bresnahan and Greenstein, 1999, Gawer and Cusumano, 2008). Thus, mutually understood technologies between and even among ecosystem partners can help them to access to resolve partners' complex resources and knowledge which then enable the co-creation of value in such partnerships.

This study makes three important contributions to the existing B2B partnership literature. First, it examines how technological firms overcome from the fundamental dilemma in a partnership (i.e., value maximization vis-à-vis risk minimization), particularly to high-tech firms that protecting their own core-competences and resources is one of determinant factors in the market. Second, it introduces concepts of technological platform and theoretically connects it with adaptation and dependence at an inter-firm level. By doing so, it extends the existing partnership management to value co-creation in the platform partnership context. Third, our study uncovers the key underlying mechanisms how heterogonous high-tech firms depend on a partner through technological adaptation to the partner's context. Thus, it demonstrates that technological knowledge accessing the mechanisms, not knowledge acquisition per se, through which heterogonous firms specialize their technological knowledge and know-how to co-create value. 


\section{CONCEPTUAL BACKGROUND}

\subsection{Dynamics of inter-firm technology exchange}

Extant technology partnership research shows that there are different types of interfirm relationships in high-tech industries (Ohmae, 1989, Hagedoorn and Narula, 1996, Narula and Hagedoorn, 1999) such as equity-based partnerships, including joint R\&D agreement and non-equity based partnerships, e.g., co-development contract, technology licensing, and technology sharing. In the fast changing technology environments, high-tech firms form a partnership to access the complementary resources of potential partners (Doz, 1988, Grant and Baden-Fuller, 2004). For instance, technological partnerships between Microsoft and Intel (Wintel) and that between ARM and Google (Armdroid) are the good examples. As such, firms prefer non-equity based partnerships for initially taking their technological positions in the turbulent industry environments (Lai and Chang, 2010, Tallman and Shenkar, 1990). Thus, 'non-equity forms of agreements tend to be more efficient for undertaking activity in more research-intensive industries' (Cantwell and Narula, 2001, p.165). As R\&D investment increases a firm's innovation-creating capability (Cohen and Levinthal, 1990), it mirrors the proxy of innovative performance of firms (Teece, 1996, Berchicci, 2013). In this vein, partnering firms through technological exchange benefit from such interfirm relationships in that 'attracting technology through their alliances and companies concentrating on $R \& D$ cooperation have significant higher rate of profit' (Hagedoorn and Schakenraad, 1994, p.300). Thus, firms forming technological partnerships in knowledge intensive high-tech sectors (e.g., software, computer, semiconductor, and pharmaceuticals) invest more R\&D for innovation (Osborn and Baughn, 1990) and technological partnerships (Mariana, 2009). At the same time, they need to properly govern their own technology resource exchanges in partnerships, as the governance structure of the quasi-market (e.g., equity-based contracts) is not a perfect organizational form to share and protect their core 
knowledge and skills. Therefore partnering firms need to control inter-organizational knowledge exchange in a partnership (Bala and James, 2007).

Firms operating in the complex high-tech and knowledge-intensive industry deal with more complex technological knowledge transfers than those in the low-tech sector due to knowledge tacitness (Inkpen, 2000, Kogut and Zander, 1993). In this regard, such firms make high levels of investment for new technology development (Cantwell and Fai, 1999, Palaskas and Tsampra, 2003). From the resource and capability perspective, firms which develop and manage technologically complex products can benefit from valuable external complementary resources (Mitchell and Singh, 1996, Lavie, 2006). For example, Lubatkin et al. (2001, p.1354) emphasize the importance of complementary alliances and suggest that such alliances 'make it possible for firms to jointly develop and leverage competencies which they could not develop alone'. Therefore, firms entering technological partnerships in high-tech industries ought to identify whether potential partners are capable of complementing their technological innovation (Emden et al., 2006, Mariana, 2009).

\subsection{Complementarity and technological adaptation in the platform environment}

Resource complementarity can lead to technology dependence on a partner in that a firm makes an effort to acquire complementary resources for attaining competitive advantage from the resource-based view perspective (Richey et al., 2007, Lavie, 2006). In the inter-firm context, complementarity indicates the low level of similarity in core competencies between partnering firms (Kale et al., 2000). As such, Harrison et al. (2001) highlight that partnerships allow firms to obtain complementary resources and create value. Thus, complementary resources are important criteria for firms when selecting partners (Hitt et al., 2000, Shapiro and Varian, 1999) rather than acquiring knowledge from alliances as the key motives (Grant and Baden-Fuller, 2004). 
Resource complementarity and technological adaptation are becoming more evident in technology platforms where various participants are active (Seyoum and Lian, in press). Previous studies on platforms environments and strategies have focused more on product development optimization in the area of operations management (Robertson and Ulrich, 1998, Nobeoka and Cusumano, 1997) and on theoretical analyses of platform competition in industrial economics (Rochet and Tirole, 2003, Armstrong, 2006, Yu-Shan et al., 2018). In particular, structural studies on various two-sided markets, such as those on platform strategies, types, and structures, are under way (Eisenmann et al., 2006, Gawer and Cusumano, 2002, Kim, 2014). It enables to confirm that the resource complementarity is naturally established according to the structural characteristics of the two-sided market, and platforms encourage the participation of various stakeholders based on ecosystem and network building (Yu-Shan et al., 2018), which in turn facilitates technological partnerships for value creation. These studies have been further extended to comprehend how technological platform providers facilitate and encourage the increased support from platform participants. This partnership with platform participants offer resources to the success of platform environment due to inherent mutual dependence and engagement among the partners within the platform environment (Venkatraman and Lee, 2004). Therefore, technological platform providers focus on investing resources to induce partners to their platform in order to exchange each resource to create value for a platform's provider over time (McIntyre and Srinivasan, 2017).

In particular, the resource complementarity of platforms is constantly increasing, which positively contributes to firm performance (Zhu, 2004). Furthermore, in a technological partnership, mutually understood technological platforms can significantly improve technological collaboration among partners because of pre-defined technological protocols between engaging firms (Bresnahan and Greenstein, 1999, Gawer and Cusumano, 2008, Kim, 
2018). Thus, a mutually understood platform can help firms to access partners' resources and knowledge. Firms can create technological opportunities and successfully implement new technologies when their technologies adapt to their organizations and environments (Leonard-Barton, 1988), and it shows a further increase in between heterogeneous partners (Rietveld and Eggers, 2018).

A firm as a repository of knowledge has different technological capabilities from others (Kogut and Zander, 1992, Newbert, 2007). In the knowledge-intensive high-tech industry, high-tech firms necessarily adapt their heterogeneous technology resources to dominant industry standards or a collaborative partner's technological platform. Technological adaptations are essential for inter-firm relationships in that partners ought to modify their resources to suit the mutual parties' needs better (Brennan et al., 2003, Hallén et al., 1991). Firms in the upstream value chain accompany technology resource adaptations to products and processes of partners (Håkansson, 1982, Håkansson and Snehota, 1995). Thus, understanding complementarity and other parties' platform are critical in technological partnerships (Kavusan et al., 2016). Besides managing optimal resource governance in technological partnerships, understanding complementarity is useful for firms to manage the dynamics of technology resource exchanges in high-tech partnerships.

\section{HYPOTHESES}

\subsection{Technological Complexity, Adaptation, and Dependence}

Resource heterogeneity between firms leads to increasing degree of reciprocal technology adaptations in partnerships (Teng and Das, 2008, Mariana, 2009). So, technological partners are required to have high level of mutual adaptations to develop innovative products. Thus, both partners adapt to product technologies and development processes to meet the partners' requirements in partnerships (Mukherji and Francis, 2008) rather than merely acquiring 
knowledge from alliance partners (Grant and Baden-Fuller, 2004; Kavusan et al., 2016). High-tech firms engaging in partnerships need to identify the standard and complexity of technology in the industry, and then prospect the changes of the technology to fulfil technology requirements of the market (Shapiro and Varian, 1999). A firm's technology adaption process does not always follow gradual process but often disruptive when a firm introduce new technologies from environments and implement them in improving operational practices (Tyre and Orlikowski, 1994).

Technological partnership provide knowledge accessibility for firms by means of linking their capabilities to technology and market related knowledge (Inkpen, 2003, Lee and Cavusgil, 2006). As such, technology complementarity between partners leads to expediting interfirm technological knowledge transfers which reinforce technological capability of firms (Mowery et al., 1996); thus, the higher interdependence between firms is, the higher knowledge exchanges in partnerships are (Gulati and Singh, 1998). As 'dependency is an unavoidable by-product of a beneficial relationship' (Johanson and Vahlne, 2009, p.1418), degree of technological dependence on partners is related to the characteristics of innovative products attributable to complexity in technologies (Håkansson and Snehota, 1995, Chapman and Hyland, 2004). Particularly, product complexity is a significant indicator of dependence in interfirm relationships (Hallén et al., 1991). Based on the characteristics of complex technology of a high-tech product, technological platform partners in high-tech industries are likely to rely on complementary technology resources of their partners for the development of innovative products and quicker market commercialization with the partners. Thus, based on the above discussion, we propose that:

H1. In the technological platform partnership environments, technology complexity increases dependence on a focal partner. 
Technology adaptations of firms are often influenced by paradigmatic dominant technologies in the market (Rosenkopf and Tushman, 1994, Gereffi et al., 2005). Particularly, in a turbulent market environment, technological adaptations between partnering firms are unavoidable. Owing to technology resource heterogeneity between partnering firms and fastchanging technological environments in the high-tech industry, a partnering firm needs to adapt to the technology resources, product development process, and milestone of a complementary partner's platform, to be able to efficiently develop innovative products.

Inter-firm adaptations can be examined by linking the mutual adaptations to partner dependence. For instance, Hallén et al. (1991, p.31) postulate, 'in working business relationships, a firm adapts to a counterpart to the degree that it is dependent on that counterpart'. In particular, the platform business model has increased the importance of interdependence in partnerships (Gawer and Cusumano, 2008, Gawer, 2014). The platform provider's leadership in the form of a platform in which the market's collaborative stakeholders are involved plays an important role, and it is important to create and share value with other participants in the market based on the open platform. As a result, technologically adaptive behaviours of firms are strengthened, and relation-specific adaptations between partners in partnerships increase partner switching costs, which in turn generate partner dependence (Cannon et al., 2000). On the other hand, platform can also have network effect, which can play an important role in the co-creation of value amongst alliance partners (McIntyre and Srinivasan, 2017). Furthermore, this partner dependency contributes to long-term bilateral dependence between partners (Bennett and Gabriel, 2001). Technological resource adaptation activities in inter-firm relationships originates from resource heterogeneity, which increases partner dependence (Anderson et al., 1994, Teng and Das, 2008). Following this logic, it becomes clear that firms forming technological platform partnerships in high-tech industries need to adapt their complex technological resources to 
external resources, in order to strengthen product innovation, which affects their technology dependence on the partner. Thus:

H2. In the technological platform partnership environments, technological adaptation to a partner's platform increases dependence on the focal partner.

\subsection{Value Co-creation through Partnerships}

In the knowledge-assessing technological partnership, technological partners aim to develop their partner's knowledge base but not acquisition of the other party's knowledge (Grant and Baden-Fuller, 2004, Carayannopoulos and Auster, 2010). Given that circumstance, the partnership can facilitate knowledge sharing between the partners and specialization of individual partners (Lew et al., 2016). Thus, a focal firm's dependence on the partnership might not intend to take a superior position in the partnership. Furthermore, the focal firm's technologically adapted resources to the partner curb deceitful behaviors in the partnership. At the same time, the technological platform providers' in the partnership may not necessarily exercise its power on the technological resource dependent situation as the other collaborating party's technologies adapted to the platform make the relationship durable whist the combined resources between two partners become difficult to be detachable technologically. In addition, platform providers generate the network effect through partnership, thus making value co-creation (Cusumano and Gawer, 2002, Cusumano, 2010, Parker and van Alstyne, 2005). Platform providers and participants learn skills and share knowledge each other while maintaining core competencies (Huang et al., 2013). In such unique network relationship context, therefore dependence on a partner helps to achieve partnership goals. Value co-creation in such technological partnerships depends on cooperation, not competition or learning races, between technologically complementary partners (Kavusan et al., 2016, Mowery et al., 2002). As partner experience of success in 
joint problem solving through enhanced value co-creation accumulates, it will reinforce partnership performance. Thus, we suggest the following:

H3. In the technological platform partnership environments, dependence on a focal partner positively affects the co-creation of value in such partnerships.

\section{METHODS}

\subsection{Sample and data collection}

The research investigates the exchange mechanisms in partnerships between the software company and the hardware company We collected the sample data using survey methods and surveyed 52 software and 58 hardware firms $(n=110)^{1}$; each group was divided into six categories as shown in Table 1. With respect to software firms, 16 operation systems firms, 12 application software firms, 10 application platform firms, 4 development software firms, 2 interface/browser firms, and 8 others were selected. Regarding hardware firms, there were 19 system-on-chips firms, 13 chip design firms, 10 communication firms, 7 micro-controller firms, 1 graphics hardware firm, and 8 others. The sample firms surveyed have cooperated with small or large platform partners; therefore, they must adapt to the other party's technologies. To avoid response bias, we framed our survey questionnaire carefully and provided a simple, exhaustive set of answer options. Especially, we developed two sets of questionnaires for the software company and the hardware company respectively. Questionnaires were classified into four types. First, questions were asked about technology complexity and how well each firm adapted to the partner's platform. Thereafter, we attempted to test $H 1$ and $H 2$ by constructing a question to ascertain each firm's degree of

\footnotetext{
${ }^{1}$ We collected data from 52 software companies (i.e., focal software firms) forming partnerships with 52 hardware companies (i.e., hardware platform providers to the software firms) and 58 hardware companies (i.e., focal hardware firms) partnering with 58 software companies (i.e., software platform providers to the hardware firms).
} 
dependence on the partner. We also attempted to test $H 3$ by checking the effectiveness of overall partnership performance.

\section{$<$ Insert Figure 1 and Table 1 here >}

\subsection{Construct operationalization and measures}

Product complexity is conceptualized as the degree to which the product is technologically complicated and difficult (Sarin and Mahajan, 2001). A four-item construct was adapted from (Sarin and Mahajan, 2001). Adaptation to a partner's platform was defined as the degree to which a firm's technology resource is modified in order to suit its partner's platform (De Mazancourt et al., 2005, Hallén et al., 1991), we adapted three items from the study of mutual adaption study of (Mukherji and Francis, 2008). Dependence on a partner is conceptualized as the degree to which a firm's technology resource depends on its partner. Based on Ganesan (1994), a four-item construct was formulated to capture a focal firm's dependence on a partner. To measure partnership performance, we adopted three items from the contributions of Arino (2003) and Norman (2004).

In addition, we controlled for pervious partnership experience, partnership age, and a focal firm's size. First, network-specific experiences between partners may develop better resource exchange routines. Partnership experience is coded as 1 for a having experience with this paper, otherwise 0 . Second, we controlled for partnership age (the number of years since forming this partnership) as structural capital developed between partners which have longer network relationships may influence performance of those partnerships. Lastly, larger firms may possess superior resources and technological capabilities than smaller firms. A focal firm's size (the natural logarithm of sales revenues) was controlled for in the model. The following Table 2 summarizes the measures of main constructs employed in this research.

$<$ Insert Table 2 and Table 3 here > 


\section{RESULTS}

\subsection{Validity and reliability}

We examined the quality of the measurement model in terms of validity and reliability. Following Fornell-Larcker (1981) criterion, in order to examine discriminant validity squared root figures of average variance extracted (AVE) of each construct are compared with correlations among study constructs. As shown in Table 2, the squared root figures are higher than correlations among the constructs. Heterotrait-Monotrait (HTMT) ratio of correlation values range from 0.167 high up to 0.569 , which are lower than 0.9. The results of HTMT test also indicate that discriminant validity exists in the measurement model (Henseler et al., 2015). Regarding convergence validity, as presented in Table 2 all AVE figures of study contract are over 0.5, suggesting convergence validity of the model (Fornell and Larcker, 1981). The reliability of measures was tested using alpha, composite reliability, and outer loading values. As shown in Table 3, composite reliability values of all study constructs are over 0.8 and Cronbach's alpha of them are higher than 0.6 (Malhotra, 2010). Also, all outer loading values of each construct are all higher than 0.5 , assuring the reliably of the measurement model (Joe et al., 2014).

\subsection{Hypothesis test}

Partial least squares structural equation modelling (PLS-SEM) was used for testing research hypotheses. PLS-SEM allows for examining the structural relationships among reflective constructs including factor models, and the bootstrap allows for estimating the model parameters using relatively a small sample size (Henseler et al., 2016). PLS-SEM is suitable for examining an early-stage explorative theory-testing model (Dana and Dawes, 2004, Hair et al., 2014). Also, a bootstrapping technique of PLS-SEM helps to parameter estimates and standard errors (Rigdon, 2016), thus a relatively small size of the current research $(n=110)$. We applied PLS algorithm to estimate standardized path coefficients in the structural model, 
and then setup 5,000 subsamples to conduct a two-sided significance test (Henseler et al., 2016).

Regarding $H \mathrm{l}$, the path from technology complexity to dependence on a partner was positively significant (path coefficient $=0.212, \mathrm{p}<0.05$ ). Thus, $H 1$ is supported. The impact of adaptation on a partner's platform was positively significant (path coefficient $=0.406$, p $<0.001$ ), suggesting supported $H 2$. Regarding $H 3$, the path from dependence on a partner to partnership performance was significant (path coefficient $=0.231, \mathrm{p}<0.1$ ), indicating partial support for $H 3$. Figure 2 presents the results of the validated SEM, including each path coefficient and outer-loading value and explained $R^{2}$. After testing the hypotheses, we also examined the predictive relevance of the model using blindfolding cross-validated communality $\left(Q_{c o m m}{ }^{2}\right)$ and redundancy $\left(Q_{\text {red }} 2\right)$ statistic (Streukens and Leroi-Werelds, 2016, Wold, 1982). The results show that values for $Q_{c o m m}{ }^{2}$ and $Q_{\text {red }}{ }^{2}$ of constructs show are all positive, thus predictive relevance of the model (Chin, 1998).

\section{< Insert Figure 2 here >}

\section{DISCUSSION AND CONCLUSIONS}

\subsection{Theoretical implications}

There has been an increasing interests in understanding how platforms oriented firms cocreate value (e.g., Gawer, 2014). With the advent of the increasingly complex high-tech industry and rise of digitization (Amit and Han, 2017), there exist companies with diverse tendencies and technologies, making collaboration and partnerships more important than ever for the co-creation of value (e.g., Kavusan et al., 2016, Mowery et al., 2002, Grant and Baden-Fuller, 2004). In other words, it is imperative to understand how different firms with heterogeneous set of resources can develop impactful partnerships for value creation whilst minimizing risks in the platform-based economy. In particular, platform increases partners' 
dependence (Cusumano and Gawer, 2002), which would in turn affects technological activities between platform partners and the co-creation of value in such partnerships. As such, this study aimed to investigate the dilemma within platforms- oriented partnerships context and how to maximize value creation while minimizing inter-partner risks and knowledge leakage in such contexts. It fundamentally assumes the heterogeneity of an individual firm's value-creating mechanisms owing to different resources and organizational capabilities which are embedded in the platform. Thus, knowledge hoarding and protection are main concerns among collaborative partners (Fey and Birkinshaw, 2005). The theoretical implications of this study are summarized as follows.

First, we find that the platform plays the role of a knowledge-accessing partnership, affecting the co-creation of value and enhancing partnerships' effectiveness. A focal firm's technological complexity and technological adaptation to its partner's platform increase partner's dependence. As such the platform providers who controls critical technologies and have complex platform derive more power leading to the dependence of low- complexity platforms providing partners as per the resource dependency theory (e.g., Pfeffer and Salancik, 1978b). This phenomenon has a positive effect on partnerships between companies and was found to be particularly high in high-tech firms. This finding suggests that firms with high technological complexity can exhibit higher partner dependence to overcome the relative weaknesses of their core competencies. In such circumstances, negative resource dependence concerns such as power asymmetry and lock-in effect would be lessened (see Xia, 2011). Thus, firms with complex technologies participate in a fair exchange of values demonstrated through a platform, which allows them to interact with each other and deliver new values and benefits. Recently, we have observed the rise of platforms oriented high-tech firms and such firms have emerged by utilizing multisided platforms and have connected customers and network partners by using their unique platforms (Hagiu and Wright, 2015, 
Rochet and Tirole, 2003). As such, these firms value creation is different compared to traditional firms who exclusively depend on utilizing internal resources or knowledge acquisitions from their alliance partners in order to effectively compete in their given industry. The platform firms on the other hand could access complementary knowledge from other specialized firms in order to create value (Gawer and Cusumano, 2014, McIntyre and Srinivasan, 2017, Rochet and Tirole, 2003, Hagiu, 2014).

Second, we unveil the knowledge specification and co-value creation in the knowledgeaccessing partnership. In general, decisions about whether a company will share its knowledge with others will depend on the functional relationship between benefits and costs. In other words, if the benefit of knowledge sharing is greater than the cost, firms will be more active in knowledge sharing. The results of this study demonstrate that high-tech firms cocreate value through knowledge sharing, not knowledge acquisition per se (Grant and BadenFuller, 2004, Buckley et al., 2009). In other words, high-tech firms were able to co-create value, while at the same time allowing mutual knowledge accessing through the platform.

\subsection{Managerial implications}

In this study, we empirically investigated whether high-tech firms with high technical identity through their knowledge-accessing alliances strengthen their partnerships by increasing their dependence on each other. We found that the greater the knowledge sharing through the partner's platform, regardless of the technical heterogeneity of the company, the higher the effect on partnership performance. This indicates that knowledge-accessing partners between different high-tech industries can co-create value through technological adaptations and mutual dependence on their partners. In fact, one of the reasons why platform-oriented companies are paying close attention to partnerships is to maximize synergy creation through mutual knowledge sharing and deliver superior performance. 
Mutual knowledge sharing refers to mutual learning about development strategy and policy. It means organizing and preserving knowledge so that the organization acquires knowledge systematically through internal and external researches and experiences with easy access. According to the OECD (2013), more than 50\% of the gross national product of developed countries is generated in the knowledge industry. This is an example showing that the source of economic wealth is moving from material assets to intangible assets such as knowledge, patents and ideas. This suggests that companies need to acquire valuable knowledge and competencies to effectively utilize them to secure competitiveness. The importance of collaborative efforts is growing more as technology advances.

High-tech companies can develop various modes of knowledge exchange mechanisms to understand the partners' knowledge, and, the higher the adaptation to the platform of the partner with the complex technology, the higher the partnership performance. The results of this study show that companies can have common value creation through knowledgeaccessing alliances by adopting open technology rather than closed technology. Today, with the transition to a knowledge-based economy and global competition, the open innovation environment is seen as a trend in the world. Companies are using open innovation strategies to cope with the rapidly changing rate of technological innovation, strengthen market dominance and secure original technology. Previously, companies developed their own technologies. However, due to the sophistication of products and the increase in intellectual property rights, joint research and partnership with other organizations became more important. For instance, when a company manufactured a VHS video, only 3 patent license agreements were required. However, DVD players need 35 patent license agreements, and Blu-ray disc players need 60 patent license agreements.

These environmental changes make that knowledge stealing and acquisition is of less concern in the knowledge-accessing alliances, and partner dependence is strong. In such 
partnerships, mangers need to focus more on technological adaptation to remove technological problems while jointly working on a project. In so doing, they can facilitate technological coordination and commitment to the partnership, and thus better performance. Our study provides useful managerial implications on how technological partners can cocreate value and enhance partnership performance in the high-tech industry through knowledge assessing mechanisms.

\subsection{Limitations and recommendations}

Despite the useful findings and implications of this study, there are several limitations that need to be acknowledged. First, the generalization of research results may be limited because this study solely focuses on IT firms with limited sample size. Subsequent research must expand the scope of target firms and technology platforms to understand technological complexity, adaptation to a multisided platform environment, and examine the dependency and knowledge sharing for the co-creation of value in other industries. The rise of the platform economy offers greater opportunities to scholars to examine how firms coordinate with their heterogeneous alliance partners and customers to create value across developed and emerging markets, thus scholars need to pay attention to the value creation and capture mechanism adopted by sharing economy's firms. Second, the sample size of this study is not large enough for allowing for generalization. Thus, future research should pay attention to broaden the scope of the research through additional analysis of companies in other sectors such as credit cards and mobile payments providers and examine how firms create value by taking advantage of their partners' specialized knowledge. In this study, we found that partner dependence is higher when technology complexity and technological adaptation are higher. However, factors affecting firms' partnership are diverse, but only variables that can be measured quantitatively were used. In future research, it would be helpful to improve the understanding of companies' collaborative relationships, by analysing the companies and 
various factors that derive collaborative technological development across different industries, e.g., automotive manufacturing and online portal service. Third, future studies could examine the governance structures (e.g., various equity-based partnership structures) and value creation across coopetition and collaborative alliances. Lastly, future studies need to examine how digitization facilitate or hinder the reconfiguration of resources and how firms' orchestrate resource for value creation and capture across diverse and multi-actors' innovation networks.

\section{REFERENCES}

ADNER, R. \& KAPOOR, R. 2010. Value creation in innovation ecosystems: How the structure of technological interdependence affects firm performance in new technology generations. Strategic Management Journal, 31, 306-333.

AMIT, R. \& HAN, X. 2017. Value creation through novel resource configurations in a digitally enabled world. Strategic Entrepreneurship Journal, 11, 228-242.

ANDERSON, J. C., H KANSSON, H. \& JOHANSON, J. 1994. Dyadic Business Relationships within a Business Network Context. Journal of Marketing, 58, 1-15.

ARINO, A. 2003. Measures of Strategic Alliance Performance: An Analysis of Construct Validity. Journal of International Business Studies, 34, 66-79.

ARMSTRONG, M. 2006. Competition in two - sided markets. The RAND Journal of Economics, 37, 668-691.

BAE, J. \& INSEAD, M. G. 2004. Partner Substitutability, Alliance Network Structure, and Firm Profitability in the Telecommunications Industry. Academy of Management Journal, 47, 843-859.

BALA, C. \& JAMES, H. 2007. From a hierarchy to a heterarchy of strategies: adapting to a changing context. Management Decision, 45, 642-652.

BASOLE, R. C. \& KARLA, J. 2011. On the evolution of mobile platform ecosystem structure and strategy. Business \& Information Systems Engineering, 3, 313.

BENNETT, R. \& GABRIEL, H. 2001. Reputation, Trust and Supplier Commitment: The Case of Shipping Company/Seaport Relations. Journal of Business \& Industrial Marketing, 16, 424-439.

BERCHICCI, L. 2013. Towards an open R\&D system: Internal R\&D investment, external knowledge acquisition and innovative performance. Research Policy, 42, 117-127.

BRENNAN, D. R., TURNBULL, P. W. \& WILSON, D. T. 2003. Dyadic Adaptation in Business-to-Business Markets. European Journal of Marketing, 37, 1636-1665.

BRESNAHAN, T. F. \& GREENSTEIN, S. 1999. Technological Competition and the Structure of the Computer Industry. The Journal of Industrial Economics, 47, 1-40.

BUCKLEY, P. J., GLAISTER, K. W., KLIJN, E. \& TAN, H. 2009. Knowledge Accession and Knowledge Acquisition in Strategic Alliances: The Impact of Supplementary and Complementary Dimensions. British Journal of Management, 20, 598-609. 
BURKERT, M., IVENS, B. S. \& SHAN, J. 2012. Governance mechanisms in domestic and international buyer-supplier relationships: An empirical study. Industrial Marketing Management, 41, 544-556.

CANNON, J., ACHROL, R. \& GUNDLACH, G. 2000. Contracts, Norms, and Plural Form Governance. Journal of the Academy of Marketing Science, 28, 180-194.

CANTWELL, J. \& FAI, F. 1999. Firms as the Source of Innovation and Growth: The Evolution of Technological Competence. Journal of Evolutionary Economics, 9, 331366.

CANTWELL, J. \& NARULA, R. 2001. The Eclectic Paradigm in the Global Economy. International Journal of Economics of Business, 8, 155-172.

CARAYANNOPOULOS, S. \& AUSTER, E. R. 2010. External knowledge sourcing in biotechnology through acquisition versus alliance: A KBV approach. Research Policy, 39, 254-267.

CARSON, S. J., MADHOK, A., VARMAN, R. \& JOHN, G. 2003. Information Processing Moderators of the Effectiveness of Trust-Based Governance in Interfirm R\&D Collaboration. Organization Science, 14, 45-56.

CECERE, G., CORROCHER, N. \& BATTAGLIA, R. D. 2015. Innovation and competition in the smartphone industry: Is there a dominant design? Telecommunications Policy, 39, 162-175.

CHAPMAN, R. \& HYLAND, P. 2004. Complexity and Learning Behaviors in Product Innovation. Technovation, 24, 553-561.

CHIN, W. W. 1998. The partial least squares approach to structural equation modelling. In: MARCOULIDES, G. A. (ed.) Modern methods for business research. Mahwah, NJ: Lawrence Erlbaum Associates.

COHEN, W. M. \& LEVINTHAL, D. A. 1990. Absorptive Capacity: A New Perspective on Learning and Innovation. Administrative Science Quarterly, 35, 125-152.

CUSUMANO, M. \& GAWER, A. 2002. The Elements of Platform Leadership. MIT Sloan Management Review, 43, 51-58.

CUSUMANO, M. A. 2010. Technology strategy and management The evolution of platform thinking. Communications of the ACM, 53, 32-34.

DANA, J. \& DAWES, R. M. 2004. The Superiority of Simple Alternatives to Regression for Social Science Predictions. Journal of Educational and Behavioral Statistics, 29, 317 331.

DE MAZANCOURT, C., LOREAU, M. \& DIECKMANN, U. L. F. 2005. Understanding mutualism when there is adaptation to the partner. Journal of Ecology, 93, 305-314.

DOZ, Y. L. 1988. Technology Partnerships between Larger and Smaller Firms: Some Critical Issues. In: CONTRACTOR, F. J. \& PETER, L. (eds.) Cooperative Strategies in International Business. 1st ed. Lexington: Lexington Books.

EISENMANN, T., PARKER, G. \& VAN ALSTYNE, M. W. 2006. Strategies for two-sided markets. Harvard business review, 84, 92.

EMDEN, Z., CALANTONE, R. J. \& DROGE, C. 2006. Collaborating for New Product Development: Selecting the Partner with Maximum Potential to Create Value. Journal of Product Innovation Management, 23, 330-341.

FEY, C. F. \& BIRKINSHAW, J. 2005. External Sources of Knowledge, Governance Mode, and R\&D Performance. Journal of Management, 31, 597-621.

FORNELL, C. \& LARCKER, D. F. 1981. Structural Equation Models With Unobservable Variables and Measurement Error: Algebra and Statistics. Journal of Marketing Research, 18, 382.

GANESAN, S. 1994. Determinants of Long-Term Orientation in Buyer-Seller Relationships. Journal of Marketing, 58, 1-19. 
GAWER, A. 2014. Bridging differing perspectives on technological platforms: Toward an integrative framework. Research Policy, 43, 1239-1249.

GAWER, A. \& CUSUMANO, M. 2002. Platform leadership: How Intel, Microsoft, and Cisco drive industry innovation, Harvard Business School Press Boston.

GAWER, A. \& CUSUMANO, M. 2008. How companies become platform leaders. MIT Sloan Management Review, 49, 28.

GAWER, A. \& CUSUMANO, M. A. 2014. Industry Platforms and Ecosystem Innovation. Journal of Product Innovation Management, 31, 417-433.

GEREFFI, G., HUMPHREY, J. \& STURGEON, T. 2005. The Governance of Global Value Chains. Review of International Political Economy, 12, 78-104.

GRANT, R. M. \& BADEN-FULLER, C. 2004. A Knowledge Accessing Theory of Strategic Alliances. Journal of Management Studies, 41, 61-84.

GULATI, R. \& SINGH, H. 1998. The Architecture of Cooperation: Managing Coordination Costs and Appropriation Concerns in Strategic Alliances. Administrative Science Quarterly, 43, 781-814.

H KANSSON, H. 1982. Internal Marketing and Purchasing of Industrial Goods - An Interaction Approach, New York, Wiley.

H KANSSON, H. \& SNEHOTA, I. 1995. Developing Relationships in Business Networks, New York, Routledge.

HAGEDOORN, J. \& NARULA, R. 1996. Choosing Organizational Modes of Strategic Technology Partnering: International and Sectoral Differences. Journal of International Business Studies, 27, 265-284.

HAGEDOORN, J. \& SCHAKENRAAD, J. 1994. The Effective of Strategic Technology Alliances on Company Performance. Strategic Management Journal, 15, 291-309.

HAGIU, A. 2014. Strategic decisions for multisided platforms, MIT press.

HAGIU, A. \& WRIGHT, J. 2015. Multi-sided platforms. International Journal of Industrial Organization, 43, 162-174.

HAIR, J. F., HULT, G. T. M., RINGLE, C. M. \& SARSTEDT, M. 2014. A primer on partial least squares structural equation modeling (PLS-SEM), Thousand Oaks, CA, Sage.

HALL N, L., JOHANSON, J. \& SEYED-MOHAMED, N. 1991. Interfirm Adaptation in Business Relationships. Journal of Marketing, 55, 29-37.

HARRISON, J. S., HITT, M. A., HOSKISSON, R. E. \& IRELAND, R. D. 2001. Resource Complementarity in Business Combinations: Extending the Logic to Organizational Alliances. Journal of Management, 27, 679-690.

HENSELER, J., HUBONA, G. \& RAY, P. A. 2016. Using PLS path modeling in new technology research: updated guidelines. Industrial Management \& Data Systems, $116,2-20$.

HENSELER, J., RINGLE, C. M. \& SARSTEDT, M. 2015. A new criterion for assessing discriminant validity in variance-based structural equation modeling. Journal of the Academy of Marketing Science, 43, 115-135.

HITT, M. A., DACIN, M. T., LEVITAS, E., ARREGLE, J.-L. \& BORZA, A. 2000. Partner Selection in Emerging and Developed Market Contexts: Resource-Based and Organizational Learning Perspectives. Academy of Management Journal, 43, 449-467.

HUANG, P., CECCAGNOLI, M., FORMAN, C. \& WU, D. J. 2013. Appropriability mechanisms and the platform partnership decision: Evidence from enterprise software. Management Science, 59, 102-121.

INKPEN, A. C. 2000. Learning Through Joint Ventures: A Framework Of Knowledge Acquisition. Journal of Management Studies, 37, 1019-1043.

INKPEN, A. C. 2003. Strategic Alliances. In: RUGMAN, A. M. \& BREWER, T. L. (eds.) The Oxford Handbook of International Business. Oxford: Oxford University Press. 
IRELAND, R. D., HITT, M. A. \& VAIDYANATH, D. 2002. Alliance management as a source of competitive advantage. Journal of Management, 28, 413-446.

JOE, F. H. J., MARKO, S., LUCAS, H. \& VOLKER, G. K. 2014. Partial least squares structural equation modeling (PLS-SEM): An emerging tool in business research. European Business Review, 26, 106-121.

JOHANSON, J. \& VAHLNE, J.-E. 2009. The Uppsala Internationalization Process Model Revisited: From Liability of Foreignness to Liability of Outsidership. Journal of International Business Studies, 40, 1411-1431.

KALE, P., SINGH, H. \& PERLUMUTTER, H. 2000. Learning and Protection of Proprietary Assets in Strategic Alliances: Building Relational Capital. Strategic Management Journal, 21, 217-237.

KATILA, R., ROSENBERGER, J. D. \& EISENHARDT, K. M. 2008. Swimming with Sharks: Technology Ventures, Defense Mechanisms and Corporate Relationships. Administrative Science Quarterly, 53, 295-332.

KAVUSAN, K., NOORDERHAVEN, N. G. \& DUYSTERS, G. M. 2016. Knowledge acquisition and complementary specialization in alliances: The impact of technological overlap and alliance experience. Research Policy, 45, 2153-2165.

KHANNA, T., GULATI, R. \& NOHRIA, N. 1998. The Dynamics of Learning Alliances: Competition, Cooperation, and Relative Scope. Strategic Management Journal, 19, 193-210.

KIM, J. 2014. Platform business and network strategy. STI Policy Review, 5, 57-74.

KIM, J. 2018. Market entry strategy for a digital platform provider. Baltic Journal of Management, 13, 390-406.

KIM, J., JANG, A. \& LEE, M. 2016. The Effects of Venture Companies' Core Competence and Cooperation Strategy on their Business Performance. The e-Business Studies, 17, 91-125.

KOGUT, B. \& ZANDER, U. 1992. Knowledge of the Firm, Combinative Capabilities, and the Replication of Technology. Organization Science, 3, 383-397.

KOGUT, B. \& ZANDER, U. 1993. Knowledge of the Firm and the Evolutionary Theory of the Multinational Corporation. Journal of International Business Studies, 24, 625-645.

LAI, W.-H. \& CHANG, P.-L. 2010. Corporate motivation and performance in R\&D alliances. Journal of Business Research, 63, 490-496.

LAVIE, D. 2006. The Competitive Advantage of Interconnected Firms: An Extension of the Resource-Based View. The Academy of Management Review, 31, 638-658.

LAVIE, D., KANG, J. \& ROSENKOPF, L. 2009. Balance Within and Across Domains: The Performance Implications of Exploration and Exploitation in Alliances. Organization Science, 2011, 1517-1538.

LEE, Y. \& CAVUSGIL, S. T. 2006. Enhancing Alliance Performance: The Effects of Contractual-Based versus Relational-Based Governance. Journal of Business Research, 59, 896-905.

LEONARD-BARTON, D. 1988. Implementation As Mutual Adaptation of Technology and Organization. Research Policy, 17, 251-267.

LEW, Y. K., SINKOVICS, R. R., YAMIN, M. \& KHAN, Z. 2016. Trans-specialization understanding in international technology alliances: The influence of cultural distance. Journal of International Business Studies, 47, 577-594.

LUBATKIN, M., FLORIN, J. \& LANE, P. 2001. Learning together and apart: A model of reciprocal interfirm learning. Human Relations, 54, 1353-1382.

MALHOTRA, N. K. 2010. Introduction: Analyzing Accumulated Knowledge and Influencing future Research. Review of Marketing Research. Emerald Group Publishing Limited. 
MARIANA, D. 2009. Alliances as strategic tools: A cross - industry study of partnership planning, formation and success. Management Decision, 47, 831-844.

MCINTYRE, D. P. \& SRINIVASAN, A. 2017. Networks, platforms, and strategy: Emerging views and next steps. Strategic Management Journal, 38, 141-160.

MEYER, M. H. \& SELIGER, R. 1998. Product Platforms in Software Development. Sloan Management Review, 40, 61-74.

MITCHELL, W. \& SINGH, K. 1996. Survival of Businesses Using Collaborative Relationships to Commercialize Complex Goods Strategic Management Journal, 17, 169-195

MOWERY, D. C., OXLEY, J. E. \& SILVERMAN, B. S. 1996. Strategic Alliances and Interfirm Knowledge Transfer. Strategic Management Journal, 17, 77-91.

MOWERY, D. C., OXLEY, J. E. \& SILVERMAN, B. S. 2002. The two faces of partnerspecific absorptive capacity: learning and co-specialization in strategic alliances. In: CONTRACTOR, F. \& LORANGE, E. (eds.) Cooperative Strategies and Alliances. London: Elsevier.

MUKHERJI, A. \& FRANCIS, J. D. 2008. Mutual Adaptation in Buyer-Supplier Relationships. Journal of Business Research, 61, 154-161.

NARULA, R. \& HAGEDOORN, J. 1999. Innovating through Strategic Alliances: Moving towards International Partnerships and Contractual Agreements. Technovation, 19, 283-294.

NEWBERT, S. L. 2007. Empirical research on the resource - based view of the firm: an assessment and suggestions for future research. Strategic Management Journal, 28, 121-146.

NISSEN, M. E., ORR, R. J. \& LEVITT, R. E. 2008. Streams of shared knowledge: computational expansion of knowledge-flow theory. Knowledge Management Research \& Practice, 6, 124-140.

NOBEOKA, K. \& CUSUMANO, M. A. 1997. Multiproject strategy and sales growth: the benefits of rapid design transfer in new product development. Strategic Management Journal, 169-186.

NORMAN, P. M. 2004. Knowledge acquisition, knowledge loss, and satisfaction in high technology alliances. Journal of Business Research, 57, 610-619.

OHMAE, K. 1989. The Global Logic of Strategic Alliances. Harvard Business Review, 67, 143-154.

OSBORN, R. N. \& BAUGHN, C. C. 1990. Forms of Interorganizational Governance for Multinational Alliances Academy of Management Journal, 33, 503-519.

PALASKAS, T. \& TSAMPRA, M. 2003. National Innovation Systems: Absorptive Capacity and Firm Competitiveness. In: CANTWELL, J. \& MOLERO, J. (eds.) Multinational enterprises, innovative strategies and systems of innovation. Cheltenham: Edward Elgar Publishing.

PARKER, G. G. \& VAN ALSTYNE, M. 2005. Two-sided network effects: A theory of information product design. Management Science, 51, 1494-1504.

PARKER, G. G., VAN ALSTYNE, M. \& CHOUDARY, S. P. 2016a. Platform Revolution, New York, WW Norton.

PARKER, G. G., VAN ALSTYNE, M. \& JIANG, X. 2016b. Platform ecosystems: How developers invert the firm. MIS Quarterly, 41, 255-266.

PFEFFER, J. \& SALANCIK, G. R. 1978a. The External Control of Organizations, New York, Harper \& Row.

PFEFFER, J. \& SALANCIK, G. R. 1978b. The External Control of Organizations: A Resource Dependence Perspective, New York, Harper and Row. 
POSTREL, S. 2002. Islands of Shared Knowledge: Specialization and Mutual Understanding in Problem-Solving Teams. Organization Science, 13, 303-320.

RICHEY, R. G., DAUGHERTY, P. J. \& ROATH, A. S. 2007. Firm Technological Readiness and Complementarity: Capabilities Impacting Logistics Service Competency and Performance. Journal of Business Logistics, 28, 195-228.

RIETVELD, J. \& EGGERS, J. 2018. Demand Heterogeneity in Platform Markets: Implications for Complementors. Organization Science.

RIGDON, E. E. 2016. Choosing PLS path modeling as analytical method in European management research: A realist perspective. European Management Journal, 34, 598605.

ROBERTSON, D. \& ULRICH, K. 1998. Planning for Product Platforms. Sloan Management Review, 39, 19-31.

ROCHET, J. C. \& TIROLE, J. 2003. Platform competition in two - sided markets. Journal of the European Economic Association, 1, 990-1029.

ROSENKOPF, L. \& TUSHMAN, M. L. 1994. The Coevolution of Technology and Organization. In: BAUM, J. A. C. \& SINGH, J. V. (eds.) Evolutionary dynamics of organizations Oxford: Oxford University Press.

SARIN, S. \& MAHAJAN, V. 2001. The Effect of Reward Structures on the Performance of Cross-Functional Product Development Teams. Journal of Marketing, 65, 35-53.

SEYOUM, B. \& LIAN, Y. in press. Market performance implications of modularization: Evidence from global auto firms operating in China. International Business Review.

SHAPIRO, C. \& VARIAN, H. R. 1999. Information Rule, Boston, Harvard Business School Press.

STREUKENS, S. \& LEROI-WERELDS, S. 2016. Bootstrapping and PLS-SEM: A step-bystep guide to get more out of your bootstrap results. European Management Journal, 34, 618-632.

SYDOW, J., SCHREY GG, G. \& KOCH, J. 2009. Organizational Path Dependence: Opening the Black Box. Academy of Management Review, 34, 689-709.

TALLMAN, S. B. \& SHENKAR, O. 1990. International Cooperative Venture Strategies: Outward Investment and Small Firms from NICs. MIR: Management International Review, 30, 299-315.

TEECE, D. J. 1996. Firm Organization, Industrial Structure, and Technological Innovation. Journal of Economic Behavior \& Organization, 31, 193-224.

TENG, B.-S. \& DAS, T. K. 2008. Governance Structure Choice in Strategic Alliances. Marketing Decision, 46, 725-742.

TYRE, M. J. \& ORLIKOWSKI, W. J. 1994. Windows of Opportunity: Temporal Patterns of Technological Adaptation in Organizations. Organization Science, 5, 98-118.

VENKATRAMAN, N. \& LEE, C.-H. 2004. Preferential linkage and network evolution: A conceptual model and empirical test in the US video game sector. Academy of Management Journal, 47, 876-892.

WANG, Y. \& RAJAGOPALAN, N. 2015. Alliance capabilities: review and research agenda. Journal of Management, 41, 236-260.

WERNERFELT, B. 1984. A resource-based view of the firm. Strategic Management Journal, $5,171-180$.

WILLIAMSON, O. E. 1991. Comparative Economic Organization: The Analysis of Discrete Structural Alternatives. Administrative Science Quarterly, 36, 269-296.

WOLD, H. 1982. Soft modeling: The basic design and some extensions. In: J RESKOG, K., WOLD, S. \& WOLD, H. (eds.) Systems under indirect observation: Causality, structure, prediction. Amsterdam: Elsevier. 
XIA, J. 2011. Mutual dependence, partner substitutability, and repeated partnership: the survival of cross - border alliances. Strategic Management Journal, 32, 229-253.

YU-SHAN, S., ZONG-XI, Z. \& JIN, C. 2018. A multi-platform collaboration innovation ecosystem: the case of China. Management Decision, 56, 125-142.

YU, C.-M. J., LIAO, T.-J. \& LIN, Z.-D. 2006. Formal governance mechanisms, relational governance mechanisms, and transaction-specific investments in suppliermanufacturer relationships. Industrial Marketing Management, 35, 128-139.

ZENG, M. \& CHEN, X.-P. 2003. Achieving Cooperation in Multiparty Alliances: a Social Dilemma Approach to Partnership Management. Academy of Management Review, 28, 587-605.

ZHU, K. 2004. The complementarity of information technology infrastructure and ecommerce capability: A resource-based assessment of their business value. Journal of management information systems, 21, 167-202.

ZOLLO, M., REUER, J. J. \& SINGH, H. 2002. Interorganizational Routines and Performance in Strategic Alliances. Organization Science, 13, 701-713.

\section{TABLES AND FIGURES}

Table 1: Sample firms

\begin{tabular}{rccrcc}
\hline Software firms & number & $\%$ & Hardware firms & number & $\%$ \\
\hline Operation systems & 16 & $31 \%$ & System-on-chips & 19 & 33 \\
Application SW & 12 & $23 \%$ & Chip design & 13 & 22 \\
Application platform & 10 & $19 \%$ & Communications & 10 & 17 \\
Development SW & 4 & $5 \%$ & Micro-controller & 7 & 12 \\
User interface/Browser & 2 & $4 \%$ & Graphics & 1 & 2 \\
Others & 8 & $15 \%$ & Other hardware & 8 & 14 \\
\hline Total & $\mathbf{5 2}$ & $\mathbf{4 7 . 3 \%}$ & Total & $\mathbf{5 8}$ & $\mathbf{5 2 . 7} \%$ \\
\hline
\end{tabular}

Table 2: Correlations and discriminant validity

\begin{tabular}{lrrrrrrr}
\hline & \multicolumn{1}{c}{1} & \multicolumn{1}{c}{ 2 } & \multicolumn{1}{c}{3} & \multicolumn{1}{c}{4} & 5 & 6 & 7 \\
\hline 1. Firm size & - & & & & & & \\
2. Partnership year & -0.010 & - & & & & & \\
3. Previous experience & 0.079 & 0.112 & - & & & & \\
4. Technology complexity & 0.298 & 0.133 & 0.154 & $\mathbf{0 . 7 4 7}$ & & & \\
5. Adaptation to a platform & -0.042 & -0.070 & -0.091 & 0.142 & $\mathbf{0 . 8 4 0}$ & & \\
6. Dependence on a partner & 0.210 & 0.035 & 0.152 & 0.269 & 0.436 & $\mathbf{0 . 7 2 3}$ & \\
7. Partnership performance & -0.143 & -0.011 & 0.045 & 0.121 & 0.144 & 0.194 & $\mathbf{0 . 8 3 2}$ \\
\hline
\end{tabular}

Note: bold italicized diagonal figures indicate the square root of AVE of each main construct. 
Table 3: Measures

\begin{tabular}{|c|c|c|c|}
\hline Constructs & Mean & SD & $\mathbf{O L}$ \\
\hline \multicolumn{4}{|l|}{$\begin{array}{ll}\text { Technology complexity } & (\mathrm{AVE}=0.559, \text { alpha }=0.782, \mathrm{CR}=0.832)\end{array}$} \\
\hline This product is technically complex to develop. & 5.591 & 1.363 & 0.582 \\
\hline The development process associated with this product is relatively complex. & 5.155 & 1.301 & 0.910 \\
\hline Development of this product needs innovative technology. & 5.591 & 1.136 & 0.710 \\
\hline This product developed by my company is relatively complex. & 5.773 & 1.268 & 0.752 \\
\hline \multicolumn{4}{|l|}{ Adaptation to a partner's platform $\quad(\mathrm{AVE}=0.706$, alpha $=0.791, \mathrm{CR}=0.878)$} \\
\hline $\begin{array}{l}\text { My company modifies our technology resource to suit the requirements of this } \\
\text { partner's platform. }\end{array}$ & 4.473 & 1.406 & 0.788 \\
\hline $\begin{array}{l}\text { My company modifies our product development process to suit the requirements } \\
\text { of this partner's platform. }\end{array}$ & 4.145 & 1.445 & 0.912 \\
\hline $\begin{array}{l}\text { My company modifies our product development milestone to suit the } \\
\text { requirements of this partner's platform. }\end{array}$ & 4.136 & 1.456 & 0.816 \\
\hline \multicolumn{4}{|l|}{ Dependence on a partner $\quad(\mathrm{AVE}=0.523$, alpha $=0.695 \mathrm{CR}=0.813)$} \\
\hline My company relies on complementary technologies from this partner & 4.645 & 1.431 & 0.738 \\
\hline $\begin{array}{l}\text { This partner's technologies are important to my company's product } \\
\text { development }\end{array}$ & 5.127 & 1.271 & 0.640 \\
\hline $\begin{array}{l}\text { It would be difficult to replace this partner's technologies with another } \\
\text { organization's technologies in the market }\end{array}$ & 3.964 & 1.414 & 0.782 \\
\hline $\begin{array}{l}\text { If the partnership terminates, my company will not immediately find a good } \\
\text { alternative. }\end{array}$ & 3.809 & 1.511 & 0.724 \\
\hline \multicolumn{4}{|l|}{$\begin{array}{ll}\text { Partnership Performance } & (\mathrm{AVE}=0.691, \text { alpha }=0.776, \mathrm{CR}=0.869)\end{array}$} \\
\hline Overall, my company has achieved its goals from the partnership & 5.209 & 1118 & 0.912 \\
\hline Overall, the partnership with this partner is satisfactory & 5.255 & 0.990 & 0.886 \\
\hline $\begin{array}{l}\text { Overall, the skills and knowledge learned from the partner positively influence } \\
\text { other businesses within my company }\end{array}$ & 5.227 & 1.037 & 0.676 \\
\hline
\end{tabular}

Note: AVE (average variance extracted), CR (composite reliability), SD (standard deviation), OL (outer loading)

Figure 1: Results of SEM

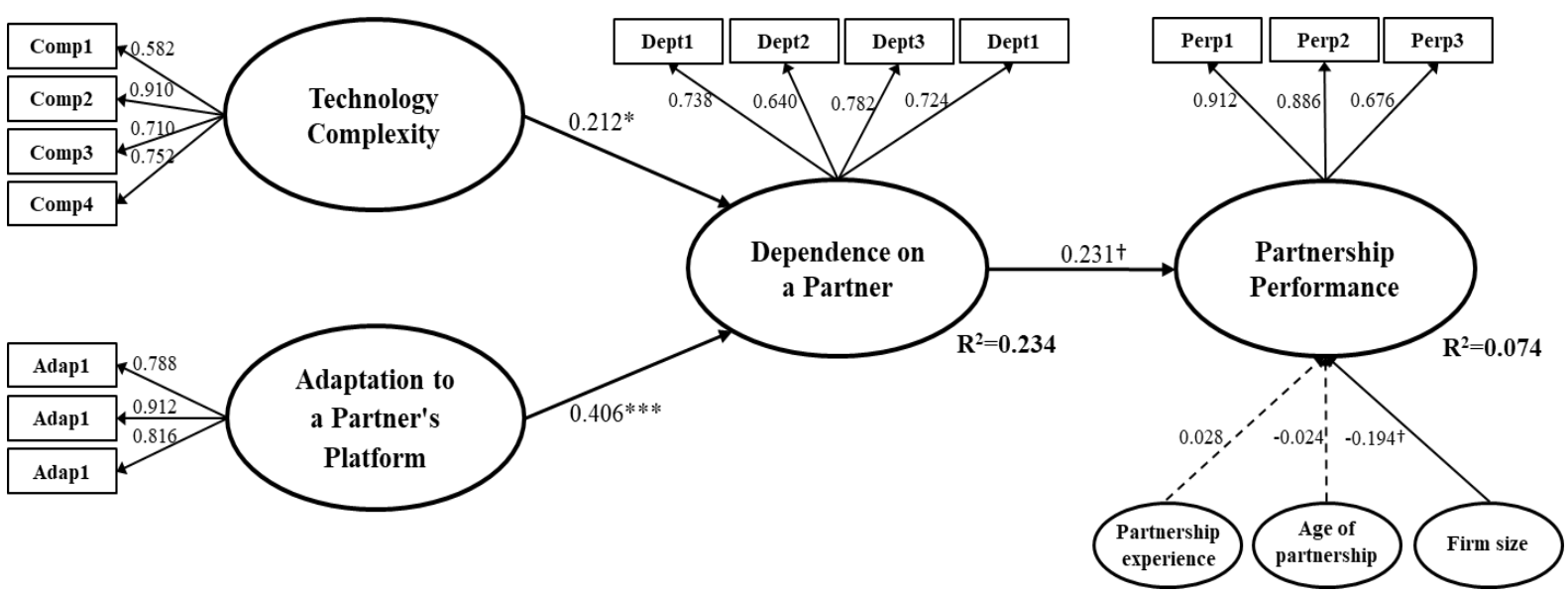

$\dagger p<0.1, * p<0.05, * * * p<0.001$ 